\title{
Release of endogenous vasopressors during and after cardiopulmonary resuscitation
}

\author{
Karl H Lindner, Thomas Haak, Andreas Keller, Ulrich Bothner, Keith G Lurie
}

\begin{abstract}
Objective-To assess whether plasma endothelin, adrenaline, noradrenaline, arginine vasopressin, adrenocorticotropin, and cortisol concentrations were higher during cardiopulmonary resuscitation in patients in whom resuscitation was successful than in those in whom it failed, and to measure the concentrations of these hormones in the immediate post-resuscitation phase.

Design-Prospective, descriptive study.

Setting-Emergency medical service at a university hospital.

Patients -60 patients with cardiac arrest out of hospital.

Interventions-Blood samples were drawn and blood pressure and heart rate were measured during cardiopulmonary resuscitation, before and after the first dose of adrenaline was given and at 5, 15,30, and 60 minutes after the restoration of spontaneous circulation. Plasma hormone concentrations were measured by radioimmunoassays.
\end{abstract}

Results-24 of the 60 patients were successfully resuscitated and admitted to hospital: 36 were not. During cardiopulmonary resuscitation before adrenaline was given, the plasma concentration of endothelin (mean (SEM)) in resuscitated and in not resuscitated patients was $4.3(0.9) \mathrm{pg} / \mathrm{ml}$ and $5.5(0.4) \mathrm{pg} / \mathrm{ml}$ respectively (NS), adrenaline was $14 \cdot 1(2 \cdot 0) \mathrm{ng} / \mathrm{ml}$ and $25.3(3.6) \mathrm{ng} / \mathrm{ml}(P<0.01)$, noradrenaline was $5.0(0.9 \mathrm{ng} / \mathrm{ml})$ and $8.4(1.1$ $\mathrm{ng} / \mathrm{ml})(P<0.05)$, arginine vasopressin was $193(28) \mathrm{pg} / \mathrm{ml}$ and $70(9) \mathrm{pg} / \mathrm{ml}(P<$ $0 \cdot 001$ ), adrenocorticotropin was 128 (34) $\mathrm{pg} / \mathrm{ml}$ and $57(6) \mathrm{pg} / \mathrm{ml}(\mathrm{P}<0.05)$, and cortisol was 18 (3) $\mu \mathrm{g} / \mathrm{dl}$ and 15 (2) $\mu \mathrm{g} / \mathrm{dl}$ (NS). During cardiopulmonary resuscitation after adrenaline was given endothelin in resuscitated and in not resuscitated patients was $4.0(1.0) \mathrm{pg} / \mathrm{ml}$ and $5.3(0.5)$ $\mathrm{pg} / \mathrm{ml}$ (NS), adrenaline was 145 (16) $\mathrm{ng} / \mathrm{ml}$ and 201 (21) $\mathrm{ng} / \mathrm{ml}(\mathbf{P}<0.05)$, noradrenaline was $3.9(0.9) \mathrm{ng} / \mathrm{ml}$ and $8.3(1.1)$ $\mathrm{ng} / \mathrm{ml}(\mathbf{P}<0.01)$, arginine vasopressin was $177(27) \mathrm{pg} / \mathrm{ml}$ and $58(9) \mathrm{pg} / \mathrm{ml} \quad(P<$ 0.001 ), adrenocorticotropin was 234 (92) $\mathrm{pg} / \mathrm{ml}$ and $85(9) \mathrm{pg} / \mathrm{ml}(P<0.001)$, and cortisol was 17 (2) $\mu \mathrm{g} / \mathrm{dl}$ and 13 (2) $\mu \mathrm{g} / \mathrm{dl}$ (NS).

Conclusions-Despite a tremendous adrenosympathetic response, the lower arginine vasopressin and adrenocorticotropin concentrations during car- diopulmonary resuscitation in patients in whom resuscitation failed may influence vital organ perfusion and hence the success of resuscitation. Plasma concentrations of arginine vasopressin and adrenocorticotropin may have a more important effect on outcome than previously thought.

(Heart 1996;75:145-150)

Keywords: endothelin; cahecholamines; arginine vasopressin (antidiuretic hormone); cardiopulmonary resuscitation

Severe stress such as that occurring with cardiac arrest and cardiopulmonary resuscitation activates the sympathetic nervous system, causing a rise in plasma catecholamine concentrations. ${ }^{12}$ When arterial hypotension stimulates the baroreceptor reflex, other vasopressor pathways such as release of arginine vasopressin and the renin-angiotensin system, are also activated. ${ }^{34}$ In stress states, including ischaemia, circulating concentrations of endothelin, a long-lasting arterial and venous vasoconstrictor derived from endothelial cells, are increased. ${ }^{5}$ As yet, there are no reports of endothelin concentrations during and after cardiopulmonary resuscitation. The purpose of this study was to: (a) measure plasma concentrations of endothelin, adrenaline, noradrenaline, arginine vasopressin, adrenocorticotropin, and cortisol in patients in cardiac arrest and during the resuscitation effort and (b) to measure the concentrations of these hormones in the immediate post-resuscitation phase.

\section{Patients and methods}

After approval by our institutional committee on human experimentation, 60 consecutive adults with out-of-hospital arrest were included in the study. Cardiopulmonary resuscitation was performed in each case in accordance with the 1993 recommendations of the European Resuscitation Council ${ }^{6}$ and was supervised by a physician from the emergency care department of Ulm University Hospital. All patients were given $1 \mathrm{mg}$ of adrenaline intravenously during cardiopulmonary resuscitation. When resuscitation was not successful, adrenaline was administered every three minutes at increasing doses of $1 \mathrm{mg}, 3 \mathrm{mg}$, and $5 \mathrm{mg}$. Sodium bicarbonate $(1 \mathrm{mmol} / \mathrm{kg})$ was given if the second dose of adrenaline failed to restore spontaneous circulation. No further drugs were used during cardiopulmonary resuscitation. A study proto- 
col check by means of an on-site tape recording of resuscitation-related events was performed by a supplementary member of the rescue team. We excluded injured patients, patients in whom adrenaline was administered endobronchially, children under 14, and patients in whom spontaneous circulation was restored by three rapid, consecutive direct current shocks without further cardiopulmonary resuscitation measures. Restoration of spontaneous circulation was defined as the return of a spontaneous palpable carotid pulse - that is, a systolic blood pressure of approximately $60 \mathrm{~mm} \mathrm{Hg}$ for an undefined time. ${ }^{7}$ Blood samples were taken from an external jugular vein 60 to 120 seconds before and after the first adrenaline dose during cardiopulmonary resuscitation, and 5, 15,30 , and $60 \mathrm{~min}$ after spontaneous circulation was restored. Adrenaline was administered into the other external jugular vein. Each of the $10 \mathrm{ml}$ blood samples was collected in a pre-chilled polystyrene tube containing ethylenediamine tetra acetic acid (EDTA, $1 \mathrm{mg} / \mathrm{ml}$ ) and placed on ice until centrifugation. Centrifugation was done at $3000 \mathrm{rpm}$ for 10 min at $4^{\circ} \mathrm{C}$. Blood samples for plasma catecholamine measurements were collected in lithium heparinate syringes filled with $100 \mu \mathrm{l}$ of an antioxidative solution (61 mg glutathione and $76 \mathrm{mg} / \mathrm{ml}$ EDTA). The plasma was then separated, immediately frozen, and stored at $-80^{\circ} \mathrm{C}$ until analysis. At the same time that blood samples were taken, blood pressure (by sphygmomanometry with auscultation) and heart rate (by electrocardiogram monitor) were recorded.

Endothelin was measured in duplicate by an endothelin-1,2,3 sensitive radioimmunoassay (Biomedica, Vienna), as described by Haak et $a l .{ }^{8}$ Endothelin was extracted from plasma by absorption on prewashed SepPak $\mathrm{C}_{18}$ cartridges (Waters/Millipore, Watford, Hertfordshire) by slow passage of $5 \mathrm{ml}$ plasma samples in $50 \mathrm{l} / \mathrm{ml}$ acetonitrile with a vacuum manifold (Henning, Berlin). After the cartridge was washed with $4 \mathrm{ml}$ of methanol/water in a volume ratio of 10:90, the absorbed peptides were eluted by $4 \mathrm{ml}$ of the same solution in a volume ratio of $85: 15$ and dried at $37^{\circ} \mathrm{C}$ under a stream of nitrogen. Standards (human/porcine endothelin-1, Peninsula Laboratories, Belmont, California), ${ }^{125}$ I-labelled antiendothelin antibodies, and plasma extracts were dissolved in a radioimmunoassay buffer. The antibody used in these studies does not cross-react with pro endothelin-1 ("big endothelin") or endothelin-3 to a substantial degree. Furthermore, the antibody does crossreact significantly with endothelin-2, but endothelin-2 has not been found to circulate in humans. Endothelin-3 does not bind to highaffinity endothelin $n_{A}$ type receptor, which mediates vasoconstriction. ${ }^{9}$ In 50 historic controls of normal resting subjects, endothelin (mean (SEM)) was $0.9(0 \cdot 1) \mathrm{pg} / \mathrm{ml}^{8}{ }^{8}$

The analysis of plasma catecholamine concentrations was based on their selective isolation by adsorption onto surface-activated aluminium oxide at a $\mathrm{pH}$ of $8.6(2 \mathrm{M}$ Tris buffer), followed by elution with a solution containing $250 \mathrm{mg}$ EDTA, $500 \mathrm{mg}$ of sodium disulphide, and $12.5 \mathrm{ml} / 1$ of $0.2 \mathrm{M}$ acetic acid and measurement by high performance liquid chromatography with electrochemical detection (Waters Associates, Milford, Massachusetts). ${ }^{2}$ The method is sensitive to less than $10 \mathrm{pg} / \mathrm{ml}$ of adrenaline or noradrenaline. The coefficient of variation for adrenaline, calculated at an adrenaline concentration of $600 \mathrm{pg} / \mathrm{ml}$, was $6 \cdot 0$. The coefficient of variation for noradrenaline, calculated at a noradrenaline concentration of $998 \mathrm{pg} / \mathrm{ml}$, was $6 \cdot 4$. In normal humans, the ranges of resting plasma adrenaline and noradrenaline concentrations with this assay are between $50 \mathrm{pg} / \mathrm{ml}$ and $200 \mathrm{pg} / \mathrm{ml}$ and between $250 \mathrm{pg} / \mathrm{ml}$ and $500 \mathrm{pg} / \mathrm{ml}$, respectively.

We measured arginine vasopressin in duplicate by a radioimmunoassay double-antibody procedure without prior extraction of the sample, using a modification of the method described by Glick and Kagan. ${ }^{10}$ The crossreactions of the arginine vasopressin antiserum determined at $50 \%$ binding have been found to be $100 \%$ for arginine vasopressin, $0.25 \%$ for lysine arginine vasopressin, $0.001 \%$ for oxytocin, and $0.001 \%$ for vasotocin. Intra and inter assay coefficients of variation were below $7 \%$. The method is sensitive to less than $0 \cdot 8$ $\mathrm{pg} / \mathrm{ml}$. The normal range of plasma arginine vasopressin concentration is between $1 \mathrm{pg} / \mathrm{ml}$ and $3 \mathrm{pg} / \mathrm{ml}$.

Adrenocorticotropin was measured in duplicate by radioimmunoassay (adrenocorticotropin-125J IRMA Paesel, Eurodiagnostics, Frankfurt) with a sensitivity of $2 \mathrm{pg} / \mathrm{ml}$. Intraassay coefficients of variation were less than $2 \%$ in the range between $60 \mathrm{pg} / \mathrm{ml}$ and 1600 $\mathrm{pg} / \mathrm{ml}$, and inter-assay coefficients of variation were less than $6 \%$. The normal range in our laboratory is $20-50 \mathrm{pg} / \mathrm{ml}$.

Cortisol was measured in duplicate by solidphase radioimmunoassay (Coat-A-Count Cortisol-RIA, Diagnostic Products Corporation, Los Angeles) with a sensitivity of $0 \cdot 2$ $\mu \mathrm{g} / \mathrm{dl}$. Intra-assay coefficients of variation were below $2 \%$ in the range between 5 and 50 $\mathrm{mg} / \mathrm{dl}$, and inter-assay coefficients of variation were below $6 \%$. The normal range lay between $5 \mu \mathrm{g} / \mathrm{dl}$ and $25 \mu \mathrm{g} / \mathrm{dl}$. The cross-reactions of the cortisol antiserum have been determined as $100 \%$ for cortisol, $1.5 \%$ for 11 -deoxycorticosterone, $0.53 \%$ for dexamethasone, and $0.15 \%$ for progesterone.

\section{STATISTICAL ANALYSIS}

Fisher's exact test was used for categorical data and Student's $t$ test (two tailed) for unpaired and paired observations was used for continuous data. In patients admitted to hospital, oneway analysis of variance for repeated measures was used to analyse the data obtained during resuscitation and at the four points $(5,15,30$, and $60 \mathrm{~min}$ ) of observation during the postresuscitation phase. The strength of correlations between single variables was investigated with the squared Pearson product-moment correlation coefficient. All data are expressed as mean (SEM). A P value less than 0.05 was regarded as significant. 
Table 1 Demographic data and intervals for all patients

\begin{tabular}{lccc}
\hline Characteristic & $\begin{array}{l}\text { Resuscitated } \\
(n=24)\end{array}$ & $\begin{array}{l}\text { Failed resuscitation } \\
(n=36)\end{array}$ & $P$ \\
\hline Male sex & $16(67 \%)$ & $25(69 \%)$ & $1 \cdot 000$ \\
Age (yr) (mean (SEM)) & $64(3)$ & $68(3)$ & $0 \cdot 228$ \\
Witnessed arrests & $18(75 \%)$ & $24(67 \%)$ & $0 \cdot 345$ \\
$\begin{array}{l}\text { Collapse-resuscitation interval in } \\
\text { witnessed arrest (min) }\end{array}$ & $7 \cdot 0(1 \cdot 2)$ & $8 \cdot 2(2 \cdot 0)$ & $0 \cdot 445$ \\
$\begin{array}{l}\text { CPR instituted by bystander } \\
\text { Initial ECG rhythm }\end{array}$ & $7(29 \%)$ & $9(25 \%)$ & $1 \cdot 000$ \\
VF & $16(65 \%)$ & $16(44 \%)$ & $0 \cdot 194$ \\
Asystole, EMD & $8(35 \%)$ & $20(56 \%)$ & - \\
Response time (min) & $7 \cdot 8(1 \cdot 2)$ & $7 \cdot 5(1 \cdot 1)$ & $0 \cdot 685$ \\
Interval from starting CPR to & $8 \cdot 2(1 \cdot 4)$ & $7 \cdot 8(1 \cdot 6)$ & 0.899 \\
$\quad$ first adrenaline dose (min) & $14 \cdot 2(2 \cdot 5)$ & - & - \\
$\quad \begin{array}{l}\text { Interval from starting CPR to } \\
\quad \text { ROSC (min) }\end{array}$ & $110(56)$ & - & - \\
Hours of survival & $12(50 \%)$ & - & - \\
Discharged from hospital & & & - \\
\hline
\end{tabular}

Values are mean (SEM). CPR, cardiopulmonary resuscitation; EMD, electromechanical dissociation; ROSC, restoration of spontaneous circulation.

\section{Results}

Table 1 shows the demographic data and key time intervals during cardiopulmonary resuscitation. Resuscitation was possible in 24 patients and was not possible despite continuation of resuscitation efforts for at least $30 \mathrm{~min}$ in 36 . There were no significant differences between these two groups with respect to sex, age, whether the arrest was witnessed or not, whether or not a bystander instituted cardiopulmonary resuscitation, initial electrocardiogram rhythm, or response time. In witnessed arrests there was no significant difference in the collapse-resuscitation interval between those patients who could be resuscitated and admitted to hospital and those in whom spontaneous circulation could not be restored. The time between the start of cardiopulmonary resuscitation and administration of the first adrenaline dose was similar in both groups, and the interval from starting cardiopulmonary resuscitation to restoration of spontaneous circulation was $14 \cdot 2$ $(2 \cdot 5) \mathrm{min}$. All patients successfully resuscitated were haemodyamically stable for at least 60 min without catecholamine treatment. Twelve of the 24 patients who were admitted to hospital survived for an average of 110 (56) hours after the restoration of spontaneous circulation. Twelve patients were discharged from the hospital without major neurological deficits. The demographic data and key intervals during resuscitation efforts for these 12 patients were not significantly different from those for the 12 patients who died in hospital.

During cardiopulmonary resuscitation (both before and after adrenaline was given), mean plasma endothelin concentrations in hospitalised patients were not significantly different from those in patients whose circulation could not be restored (table 2). After successful resuscitation, mean endothelin concentrations ranged from $4.6(0.9) \mathrm{pg} / \mathrm{ml}$ at $5 \mathrm{~min}$ and 2.8 $(0.3) \mathrm{pg} / \mathrm{ml}$ at $60 \mathrm{~min}$ (table 3). Values in both groups of patients were significantly higher than in controls. ${ }^{8}$

Mean plasma adrenaline and noradrenaline concentrations during cardiopulmonary resuscitation were considerably higher in all patients than in normal resting subjects. Before adrenaline, the concentrations in resuscitated patients

Table 2 Plasma hormone concentrations during cardiopulmonary resuscitation in resuscitated and non-resuscitated patients before and after adrenaline administration

\begin{tabular}{|c|c|c|c|c|}
\hline \multirow[b]{2}{*}{ Hormone† } & \multicolumn{2}{|c|}{ Before adrenaline } & \multicolumn{2}{|c|}{ After adrenaline } \\
\hline & $\begin{array}{l}\text { Resuscitation } \\
(n=12)\end{array}$ & $\begin{array}{l}\text { Failed resuscitation } \\
(n=14)\end{array}$ & $\begin{array}{l}\text { Resuscitation } \\
(n=24)\end{array}$ & $\begin{array}{l}\text { Failed resuscitation } \\
(n=36)\end{array}$ \\
\hline \multirow{6}{*}{$\begin{array}{l}\text { Endothelin }(\mathrm{pg} / \mathrm{ml}) \\
(0 \cdot 6-1 \cdot 2) \\
\text { Adrenaline }(\mathrm{ng} / \mathrm{ml}) \\
(0 \cdot 05-0 \cdot 2) \\
\text { Noradrenaline }(\mathrm{ng} / \mathrm{ml}) \\
(0 \cdot 25-0 \cdot 5) \\
\text { Arginine vasopressin }(\mathrm{pg} / \mathrm{ml}) \\
(1-3) \\
\text { Adrenocorticotropin }(\mathrm{pg} / \mathrm{ml}) \\
(25-50) \\
\text { Cortisol }(\mu \mathrm{g} / \mathrm{dl}) \\
(5-25)\end{array}$} & $4 \cdot 3(0 \cdot 9)$ & $5 \cdot 5(0.4)$ & $4 \cdot 0(1 \cdot 0)$ & $5.3(0.5)$ \\
\hline & $14 \cdot 1(2 \cdot 0)$ & $25 \cdot 3(3 \cdot 6)^{\star \star}$ & $145(16) \ddagger$ & $201(21)^{\star} \ddagger$ \\
\hline & $5 \cdot 0(0 \cdot 9)$ & $8 \cdot 4(1 \cdot 1)^{\star}$ & $3.9(0.9)$ & $8 \cdot 3(1 \cdot 1)^{\star \star}$ \\
\hline & $193(28)$ & $70(9)^{\star \star \star}$ & $177(27)$ & $58(9)^{\star \star \star}$ \\
\hline & $128(34)$ & $57(6)^{\star}$ & $234(92) \dagger$ & $85(9)^{\star \star \star}$ \\
\hline & $18(3)$ & $15(2)$ & $17(2)$ & $13(2)$ \\
\hline
\end{tabular}

${ }^{\star} \mathrm{P}<0.05,{ }^{\star \star} \mathrm{P}<0.01,{ }^{\star \star \star} \mathrm{P}<0.001$ for comparisons between resuscitated and non-resuscitated patients; $+\mathrm{P}<0.01, \neq \mathrm{P}<0.001$ before and after adrenaline. Values are mean (SEM). †Normal ranges of hormone values are given in parentheses. To convert values for endothelin to $\mathrm{pmol} / 1$ multiply by $0 \cdot 402$, to convert adrenaline to $\mathrm{nmol} / 1$ multiply by $5 \cdot 458$, to convert values for nor val aline to $\mathrm{nmol} / \mathrm{l}$ multiply by 5.911 , to convert arinine vaposin to $\mathrm{pmol} / 1$ multiply by 0.922 and to convert values for adrenocorticotropin to pmol/1 multiply by 0.220 , and to convert values for cortisol to nmol/1 multiply by 27.59 .

Table 3 Plasma hormone concentrations (mean (SEM)) during cardiopulmonary resuscitation and in the postresuscitation phase in all patients

\begin{tabular}{|c|c|c|c|c|c|c|}
\hline \multirow[b]{2}{*}{ Hormone * } & \multirow[b]{2}{*}{ During $C P R$} & \multicolumn{5}{|l|}{ After ROSC } \\
\hline & & $5 \min$ & $15 \mathrm{~min}$ & $30 \mathrm{~min}$ & $60 \mathrm{~min}$ & $P$ \\
\hline \multirow{6}{*}{$\begin{array}{l}\text { Endothelin }(\mathrm{pg} / \mathrm{ml}) \\
(0 \cdot 6-1 \cdot 2) \\
\text { Adrenaline }(\mathrm{ng} / \mathrm{ml}) \\
(0 \cdot 05-0 \cdot 2) \\
\text { Noradrenalin }(\mathrm{ng} / \mathrm{ml}) \\
(0 \cdot 25-0 \cdot 5) \\
\text { Arginine vasopressin }(\mathrm{pg} / \mathrm{ml}) \\
(1-3) \\
\text { Adrenocorticotropin }(\mathrm{pg} / \mathrm{ml}) \\
(25-50) \\
\text { Cortisol }(\mu \mathrm{g} / \mathrm{dl}) \\
(5-25)\end{array}$} & $3 \cdot 7(0 \cdot 5)$ & $4 \cdot 6(0.9)$ & $4 \cdot 2(0 \cdot 7)$ & $4 \cdot 0(0 \cdot 7)$ & $2 \cdot 8(0 \cdot 3)$ & NS \\
\hline & $123(11)$ & $23(2)$ & $19(1)$ & $13(1)$ & $10(1)$ & $<0.001$ \\
\hline & $6 \cdot 1(0 \cdot 7)$ & $2 \cdot 7(0 \cdot 4)$ & $2 \cdot 1(0 \cdot 3)$ & $2 \cdot 0(0 \cdot 4)$ & $1 \cdot 8(0 \cdot 3)$ & $<0.001$ \\
\hline & $172(17)$ & $117(13)$ & $72(7)$ & $44(4)$ & $24(2)$ & $<0.001$ \\
\hline & $228(46)$ & $204(33)$ & $145(16)$ & $128(14)$ & $109(11)$ & $<0.001$ \\
\hline & $23(2)$ & $20(2)$ & $25(1)$ & $26(1)$ & $25(1)$ & $<0.05$ \\
\hline
\end{tabular}

*Normal ranges are given in parentheses. $\mathrm{P}$ value refers to analysis of repeated measures over time. ROSC restoration of spontaneous circulation; CPR, cardiopulmonary resuscitation. See table 2 for conversion factors. 
Table 4 Demographic data and time intervals of all patients with witnessed ventricular fibrillation

\begin{tabular}{|c|c|c|c|}
\hline Characteristic & $\begin{array}{l}\text { Resuscitated } \\
(n=13)\end{array}$ & $\begin{array}{l}\text { Failed resuscitation } \\
(n=11)\end{array}$ & $P$ \\
\hline Male sex & $8(62 \%)$ & $7(64 \%)$ & 1.000 \\
\hline Age (yr) (mean (SEM)) & $58(4)$ & $62(3)$ & 0.228 \\
\hline Collapse-resuscitation interval ( $\mathrm{min}$ ) & $6 \cdot 2(1 \cdot 4)$ & $6 \cdot 0(1 \cdot 8)$ & 0.930 \\
\hline CPR instituted by bystander & $4(31 \%)$ & $3(27 \%)$ & 1.000 \\
\hline Response time (min) & $6 \cdot 0(1 \cdot 1)$ & $5 \cdot 8(1 \cdot 2)$ & 0.685 \\
\hline \multicolumn{4}{|l|}{ Interval from starting CPR to } \\
\hline first adrenaline dose (min) & $7 \cdot 6(1 \cdot 0)$ & $7 \cdot 3(0 \cdot 9)$ & 0.899 \\
\hline \multicolumn{4}{|l|}{ Interval from starting CPR to } \\
\hline $\operatorname{ROSC}(\mathrm{min})$ & $12 \cdot 8(2 \cdot 6)$ & - & - \\
\hline Hours of survival & $146(42)$ & - & - \\
\hline Discharged from hospital & $7(54 \%)$ & - & - \\
\hline
\end{tabular}

Values are mean (SEM). CPR, cardiopulmonary resuscitation; EMD, electromechanical dissociation; ROSC, restoration of spontanenous circulation.

were $14 \cdot 1(2 \cdot 0) \mathrm{ng} / \mathrm{ml}$ and $5 \cdot 0(0 \cdot 9) \mathrm{ng} / \mathrm{ml}$, respectively, during cardiopulmonary resuscitation, and in patients in whom resuscitation failed concentrations were $25 \cdot 3(3.6) \mathrm{ng} / \mathrm{ml}$ and $8.4(1 \cdot 1) \mathrm{ng} / \mathrm{ml}$ (intergroup comparisons $\mathrm{P}<$ 0.01 for adrenaline and $\mathrm{P}<0.05$ for noradrenaline) (table 2). After adrenaline administration, plasma adrenaline and noradrenaline concentrations were still significantly higher in patients in whom resuscitation failed. After successful resuscitation, mean adrenaline and noradrenaline concentrations decreased to $10(1) \mathrm{ng} / \mathrm{ml}$ and $1.8(0.3) \mathrm{ng} / \mathrm{ml}$, respectively, at $60 \mathrm{~min}$ (table 3).

Mean plasma arginine vasopressin concentrations during cardiopulmonary resuscitation before adrenaline were $193(28) \mathrm{pg} / \mathrm{ml}$ in resuscitated patients and $70(9) \mathrm{pg} / \mathrm{ml}$ in those patients in whom resuscitation failed $(P<$ 0.001 ) (table 2). After adrenaline, concentrations were also significantly higher in resuscitated patients. Compared with the concentrations measured in normal subjects, concentrations were markedly increased during the first hour after successful resuscitation (table 3 ). The mean concentration of arginine vasopressin gradually decreased. There were significant differences between the arginine vasopressin concentration during cardiopulmonary resuscitation and at 15,30 , and $60 \mathrm{~min}$ after resuscitation.

Mean plasma adrenocorticotropin concentrations during cardiopulmonary resuscitation both before and after adrenaline were significantly higher in patients admitted to hospital than in those in whom spontaneous circulation could not be restored (table 2 ). In resuscitated patients values were significantly higher after adrenaline. In the first hour after spontaneous circulation was restored, mean adrenocorticotropin concentration gradually decreased to 109 (11) $\mathrm{pg} / \mathrm{ml}$ at $60 \mathrm{~min}$ (table 3). In patients admitted to hospital, there was a significant difference between the adrenocorticotropin concentration during cardiopulmonary resuscitation and at $60 \mathrm{~min}$ after spontaneous circulation was restored (table 3 ). In all cardiac arrest patients, adrenocorticotropin concentrations were higher than those measured in normal controls.

Mean plasma cortisol concentrations before and after adrenaline were not significantly higher in patients admitted to hospital than in those in whom resuscitation failed (table 2). Despite high adrenocorticotropin concentrations during and after cardiopulmonary resuscitation, plasma cortisol concentrations were within the normal range or only a little above (table 3)

Endothelin, adrenaline, noradrenaline, arginine vasopressin, adrenocorticotropin, and cortisol concentrations were not significantly different in the subgroup of 12 patients who were discharged from hospital and those in the patients who were successfully resuscitated but did not survive.

There was positive correlation between endothelin and arginine vasopressin during cardiopulmonary resuscitation in resuscitated patients before $\left(n=12, r^{2}=0.632, P<0.001\right)$ and after administration of adrenaline $(n=24$, $\left.r^{2}=0.602, \quad P<0.001\right)$. The correlation between adrenaline and noradrenaline concentrations and also between catecholamines and the other hormones was poor both during and after cardiopulmonary resuscitation. At no point after successful resuscitation could a significant correlation be found between any of the hormones and arterial blood pressure or heart rate.

Despite the fact that there were no significant differences between the successful resuscitation and failed resuscitation groups, there was a trend towards a higher percentage of unfavourable characteristics (such as age, unwitnessed arrests, asystole, and electromechanical dissociation) in the failed resuscitation group. We therefore focused on the

Table 5 Plasma hormone concentrations during cardiopulmonary resuscitation in all patients with witnessed ventricular fibrillation

\begin{tabular}{|c|c|c|c|c|}
\hline \multirow[b]{2}{*}{ Hormone } & \multicolumn{2}{|c|}{ Before adrenaline } & \multicolumn{2}{|c|}{ After adrenaline } \\
\hline & $\begin{array}{l}\text { Resuscitated } \\
(n=8)\end{array}$ & $\begin{array}{l}\text { Failed resuscitation } \\
(n=6)\end{array}$ & $\begin{array}{l}\text { Resuscitated } \\
(n=13)\end{array}$ & $\begin{array}{l}\text { Failed resuscitation } \\
(n=11)\end{array}$ \\
\hline $\begin{array}{l}\text { Endothelin }(\mathrm{pg} / \mathrm{ml}) \\
(0 \cdot 6-1 \cdot 2)\end{array}$ & $4.0(0.8)$ & $4.2(0.6)$ & $3.9(0.6)$ & $4.5(0.6)$ \\
\hline $\begin{array}{l}\text { Adrenaline }(\mathrm{ng} / \mathrm{ml}) \\
(0.05-0.02)\end{array}$ & $12 \cdot 2(1 \cdot 4)$ & $20 \cdot 6(3 \cdot 2)^{\star \star}$ & $124(18) \ddagger$ & $186(24) \ddagger^{\star}$ \\
\hline $\begin{array}{l}\text { Noradrenaline }(\mathrm{ng} / \mathrm{ml}) \\
(0.25-0.5)\end{array}$ & $4 \cdot 2(0 \cdot 8)$ & $7 \cdot 8(1 \cdot 4)^{\star}$ & $4 \cdot 0(0 \cdot 8)$ & $9 \cdot 4(1 \cdot 2)^{\star \star}$ \\
\hline $\begin{array}{l}\text { Arginine vasopressin }(\mathrm{pg} / \mathrm{ml}) \\
\quad(1-3) \\
\text { Adrenocorticotropin }(\mathrm{pg} / \mathrm{ml})\end{array}$ & $180(32)$ & $82(12)^{\star \star \star}$ & $156(24)$ & $52(8)^{\star \star \star}$ \\
\hline$(25-50)$ & $116(30)$ & $52(8)^{\star}$ & $208(86) \dagger$ & $112(18)^{\star \star \star}$ \\
\hline $\begin{array}{l}\text { Cortisol }(\mu \mathrm{g} / \mathrm{dl}) \\
\quad(5-25)\end{array}$ & $22(4)$ & $18(3)$ & $19(3)$ & $16(4)$ \\
\hline
\end{tabular}

$\star \mathrm{P}<0.05, \star \star \mathrm{P}<0.01, \star \star \star \mathrm{P}<0.001$ between resuscitated and failed resuscitated patients; $+\mathrm{P}<0.01, \neq \mathrm{P}<0.001$ before and after adrenaline. Values are mean (SEM). Normal range of hormone values are given in parentheses. See table 2 for conversion factors. 
subgroup of patients with witnessed ventricular fibrillation, and found that the demographic data of these patients were almost identical in both groups (table 4). A further analysis of hormonal data of these patients confirmed that these patients showed the same differences in hormonal profile as in the total patient population (table 5).

\section{Discussion}

Our results showed that during cardiopulmonary resuscitation, plasma arginine vasopressin and adrenocorticotropin concentrations were significantly higher in patients in whom spontaneous circulation was restored than in those who could not be resuscitated. In contrast, though plasma endothelin concentrations in the jugular vein were approximately twofold to threefold higher in resuscitated patients than in controls, there was no difference in endothelin concentrations between resuscitated and failed resuscitated patients. However, parallel increases in plasma arginine vasopressin and endothelin during cardiopulmonary resuscitation were found only in resuscitated patients. Both before and after administration of adrenaline plasma adrenaline and noradrenaline concentrations were significantly higher in patients in whom resuscitation failed than in resuscitated patients, as reported by others. ${ }^{11}$ Because there was a trend to more adverse demographic characteristics in the failed resuscitation group, we looked at patients with witnessed ventricular fibrillation and found the same hormonal pattern as in the total population.

Endothelin-1, the biologically active form of endothelin, was measured in our study because of its potentially important role in the regulation of vascular tone in several stress states. ${ }^{51213}$ Plasma endothelin concentrations are increased in patients with a number of potentially lifethreatening disorders, including congestive heart failure, myocardial infarction, ischaemic heart disease, subarachnoid haemorrhage, preeclampsia, sepsis, and vasovagal syncope. During cardiopulmonary resuscitation, we also observed a rapid release of endothelin in both resuscitated and failed resuscitated patients. This increase may play a part in peripheral vasoconstriction and in shifting blood to vital organs. ${ }^{14}$ Like arginine vasopressin, endothelin is synthesised in neurons of the paraventricular nuclei of the hypothalamus and is stored in the posterior pituitary. ${ }^{13}$ Kaufmann et al described a coincident increase in plasma endothelin and arginine vasopressin during vasovagal syncope and concluded that when syncope is associated with acute block of vasoconstrictor sympathetic outflow, the baroreceptor reflex causes release of arginine vasopressin and endothelin from the neurohypophysis. ${ }^{15}$ Both baroreceptor activation and hypoxia may account for the endothelin release during cardiopulmonary resuscitation, suggesting that release of the neurohypophyseal content is an important part of the physiological response to cardiac arrest. Once increased, plasma endothelin concentrations remained increased during the post-resuscitation phase, unlike other stress hormones such as adrena- line, noradrenaline, and arginine vasopressin. Although this is probably a result of continuous release of endothelin from endothelial cells and from the posterior pituitary, it may represent impaired clearance. It is noteworthy that in our study a positive correlation was found between endothelin and arginine vasopressin concentrations in resuscitated patients, whereas no correlation was observed between these two hormones in patients in whom resuscitation failed.

The significantly lower arginine vasopressin and adrenocorticotropin concentrations in the failed resuscitation group may be caused by an insufficient release from the posterior and anterior pituitary, the reason for this is unknown. Impaired release of endothelin from the posterior pituitary could be compensated for by release from the endothelial cells. Schultz et al reported that despite higher adrenocorticotropin concentrations in cardiac arrest cortisol concentrations were lower than reported in other stress states. ${ }^{16}$

A massive adrenosympathetic discharge was observed in patients during out-of-hospital cardiac arrest. After administration of $1 \mathrm{mg}$ adrenaline there was a further massive increase in plasma adrenaline concentration. These results accord with those of others who have reported similar findings in animal models and in humans. ${ }^{1718}$ We observed significantly higher adrenaline and noradrenaline concentrations in failed resuscitation than in successful resuscitation, both before and after adrenaline administration. Thus some release of catecholamines is critical for vital organ perfusion and restoration of spontaneous circulation, but too much is associated with a poor prognosis. It is unclear at this time whether this balance is secondary to the complex alpha and beta activities of different doses of catecholamines or to other factors critical for maintaining adequate organ perfusion.

Significant differences in hormone concentrations between the resuscitated and failed resuscitated patients demonstrate that a special hormonal constellation is associated with and may be closely linked to restoration of spontaneous circulation. An increased understanding of the complex endogenous release of stress hormones may help in the development of better ways to administer stress hormone "cocktails" to improve the outcome of patients in cardiac arrest, which at present is still poor. ${ }^{19}$

In the present study the standard drug treatment that accompanied mechanical cardiopulmonary resuscitation may have influenced plasma hormone concentrations. The interval between the start of cardiopulmonary resuscitation and administration of adrenaline was the same in all patients. Only adrenocorticotropin in resuscitated patients was significantly higher after exogenous adrenaline: this effect may have been mediated by $\beta$ adrenoceptors. ${ }^{20}$ Our study does have limitations. We were able to obtain hormonal data before adrenaline in only about $50 \%$ of cases, because our study protocol was designed to prevent any delay in adrenaline administration as a result of blood sampling. A further analysis of demographic data confirmed 
that this subgroup was representative of the entire patient population. Hormone concentrations may also be influenced by the patient's condition in the minutes and hours before cardiac arrest. But in all patients the history indicated a sudden cardiac event. We cannot exclude the possibility that the difference in plasma adrenaline concentration may reflect better mixing and/or metabolism of the exogenous adrenaline related to greater cardiac output and splanchnic flow in those who were successfully resuscitated. A lower cardiac output during cardiopulmonary resuscitation might also impair the release of pituitary arginine vasopressin and adrenocorticotropin. On the other hand, the significantly higher adrenaline and noradrenaline concentrations before adrenaline administration in patients in whom resuscitation failed demonstrate that the observed differences in hormone concentrations are not caused by differences in organ perfusion.

This study showed that plasma concentrations of endothelin, catecholamines, arginine vasopressin, and adrenocorticotropin rise rapidly during cardiopulmonary resuscitation. The pattern of endothelin and arginine vasopressin release suggest that both are released from the neurohypophysis. Despite the considerable sympathochromaffin response, the lower arginine vasopressin and adrenocorticotropin concentrations during cardiopulmonary resuscitation in patients in whom resuscitation failed may influence coronary and cerebral perfusion pressure as well as cell membrane and organ stability, and hence the success of resuscitation. Administration of arginine vasopressin seems to improve the perfusion of vital organs during cardiac arrest and it may give better results than adrenaline. ${ }^{2122} \mathrm{~A}$ more comprehensive evaluation of fundamental hormonal responses to the stress of cardiac arrest may improve outcome in patients with only a marginal chance of survival.

1 Lindner $\mathrm{KH}$, Strohmenger $\mathrm{HU}$, Prengel AW, Ensinger $\mathrm{H}$, Goertz A, Weichel T. Hemodynamic and metabolic effects of epinephrine during cardiopulmonary resuscitation in a pig model. Crit Care Med 1992;20:1020-6.

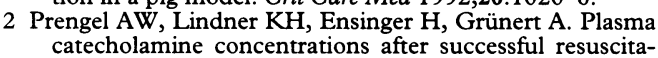
tion in patients. Crit Care Med 1992;20:609-14.
3 Shen YT, Cowley AW Jr, Vatner SF. Relative roles of cardiac and arterial baroreceptors in vasopressin regulation during hemorrhage in conscious dogs. Circ Res 1991;68: during hemo.

4 Wilson MF, Brackett DJ. Release of vasoactive hormones and circulatory changes in shock. Circ Shock 1983;11: 225-34

5 Miller RC, Pelton JT, Huggins JP. Endothelins-from receptors to medicine. Trends Pharmacol Sci 1993;14: 54-60.

6 European Resuscitation Council. Adult advanced cardiac life support: The European Resuscitation Council guidelines 1992 (abridged). Br Med F 1993;306:1589-93.

7 Cummins RO, Chamberlain DA, Abramson NS, et al. Recommended guidelines for uniform reporting of data from out-of-hospital cardiac arrest: the Utstein Style. Task Force of the American Heart Association, the European Resuscitation Council, the Heart and Stroke Foundation of Canada, and the Australian Resuscitation Council. Ann Emerg Med 1991;20:861-74.

8 Haak T, Jungmann E, Felber A, Hillmann U, Usadel KH. Increased plasma levels of endothelin in diabetic patients Increased plasma levels of endothelin in diabetic p
with hypertension. Am 7 Hypertens 1992;5:161-6.

9 Clavell A, Stingo A, Margulies K, Lerman A, Underwood D, Burnett JC, Jr. Physiological significance of endothelin: Its role in congestive heart failure. Circulation 1993; lin: Its role in congestive

10 Glick SM, Kagan A. Radioimmunoassay of arginine vasopressin. In: Jaffe BM, Behrmann HR, eds. Methods of hormone radioimmunoassays. New York: Academic Press, 1979:126-39.

11 Morisaki H, Takino Y, Ichikizaki K, Ochiai R. Sympathetic responses in out-of-hospital cardiac arrest. $\mathcal{F}$ Emerg Med 1991;9:313-6.

12 Remuzzi G, Benigni A. Endothelins in the control of cardiovascular and renal function. Lancet 1993;342:589-93.

13 Masaki T. Endothelins: Homeostatic and compensatory actions in the circulatory and endocrine systems. Endocr $\operatorname{Rev} 1993 ; 14: 256-68$

14 Ota K, Kimura T, Shoji M, Inoue $M$, Sato K, Ohta $M$, et al. Interaction of ANP with endothelin on cardiovascular, renal, and endocrine function. Am f Physiol 1992;262: E135-41.

15 Kaufmann H, Oribe E, Oliver JA. Plasma endothelin during upright tilt: Relevance for orthostatic hypotension. ing upright tilt: Relevan
Lancet 1991;338:1542-5.

16 Schultz CH, Rivers EP, Feldkamp CS, Goad EG, Smithline HA, Martin GB, et al. A characterization of hypothalamic-pituitary-adrenal axis function during and after human cardiac arrest. Crit Care Med 1993;21: 1339-47.

17 Lindner KH, Ahnefeld FW, Bowdler IM, Prengel AW. Influence of epinephrine on systemic, myocardial, and cerebral acid-base status during cardiopulmonary resuscitation. Anesthesiology 1991;74:333-9.

18 Wortsman J, Frank S, Cryer PE. Adrenomedullary response to maximal stress in humans. Am $\mathcal{F}$ Med 1984; 77:779-84.

19 Brown CG, Martin DR, Pepe PE, Stueven H, Cummins $\mathrm{RO}$, Gonzalez E, et al. A comparison of standard-dose and high-dose epinephrine in cardiac arrest outside the hospital. N Engl $\mathcal{F}$ Med 1992;327:1051-5.

20 Tilders FJ, Berkenbosch F, Vermes I, Linton EA, Smelik PG. Role of epinephrine and vasopressin in the control of PG. Role of epinephrine and vasopressin in the control of
the pituitary-adrenal response to stress. Fed Proc 1985; the pituitary

21 Lindner KH, Brinkmann A, Pfenninger EG, Lurie KG, Goertz A, Lindner IM. Effect of vasopressin on hemodynamic variables, organ blood flow, and acid-base status in a pig model of cardiopulmonary resuscitation. Anesth Analg 1993;77:427-35.

22 Lindner KH, Prengel AW, Pfenninger EG, Lindner IM, Strohmenger H-U, Georgieff $\mathrm{M}$, et al. Vasopressin mproves vital organ blood flow during closed-chest cardiopulmonary resuscitation in pigs. Circulation 1995;91: 215-21. 